\title{
EFFECT OF AGE AT FIRST CALVING AND CALVING INTERVAL LENGHT ON MILK PERFORMANCE IN COWS
}

\section{WPŁYW WIEKU W DNIU PIERWSZEGO WYCIELENIA ORAZ DŁUGOŚCI OKRESU MIĘDZYWYCIELENIOWEGO NA UŻYTKOWOŚĆ MLECZNA KRÓW}

\author{
Department of Ruminant Science, West Pomeranian University of Technology, Szczecin, Poland
}

\begin{abstract}
Streszczenie. Badania przeprowadzono w województwie kujawsko-pomorskim. Materiał badawczy stanowiły 103 krowy rasy polskiej holsztyńsko-fryzyjskiej odmiany czarno-białej (phf, $\mathrm{cb}$ ); uwzględniono wybrane parametry rozrodu - wiek pierwszego wycielenia (WPW) oraz okres międzywycieleniowy (OMW). Dane dotyczące użytkowości mlecznej i wybranych parametrów rozrodczych uzyskano z dokumentacji hodowlanej gospodarstwa, korzystając z wyników oceny wartości użytkowej bydła mlecznego, prowadzonej przez Polską Federację Hodowców Bydła i Producentów Mleka. Użytkowość mleczną krów oceniano na podstawie wydajności mleka, tłuszczu i białka [kg] oraz zawartości tych składników w mleku [\%]. Analizując okres międzywycieleniowy krów, zaobserwowano istotne różnice $(P \leq 0,05)$ pomiędzy badanymi grupami zwierząt. Najwyższą wydajność mleczną $(8481 \mathrm{~kg})$ oraz wydajność tłuszczu $(355 \mathrm{~kg})$ osiągnęły krowy w drugiej laktacji, u których okres międzywycieleniowy trwał powyżej 471 dni.
\end{abstract}

Key words: milk yield, age of first calving, interval.

Słowa kluczowe: użytkowość mleczna, wiek pierwszego wycielenia, okres międzywycieleniowy.

\section{INTRODUCTION}

At present $95 \%$ of dairy cattle are Holstein-Friesian breed of black-and-white breed. This breed is one of the most popular breeds of dairy cows in the world, achieving the highest milk yields. For years, intensive breeding has been carried out to create a breed of cattle with one direction of use, and above all with high milk yield. Improvement of this breed has now led to the creation of cows representing modern type of milk yield, with an estimated milk yield of $5.500-11.000 \mathrm{~kg}$, and a milk fat content of $3.9-4.2 \%$ and $3.2-3.6 \%$. According to PFHBIPM, the average age of first calving in 2016 in Poland was 817 days, while the interval was 431 days. The average age of the first calving of cows in Poland in 2015 was 824 days, and in 2016 the first calving age was shortened to 817 days. Considering the Kujawsko-Pomorskie voivodeship, the age of first calving slightly different. In 2015 it amounted to 804 days, the next year shortened by 4 days (800 days). In the Zachodniopomorskie voivodeship, the average intergalactic period was 429 days in 2015 and 426 days in the following year.

Corresponding author - Adres do korespondencji: Ewa Czerniawska-Piątkowska, Department of Ruminant Science, West Pomeranian University of Technology, Szczecin, Klemensa Janickiego 29, 71-270 Szczecin, Poland, e-mail: ewa.czerniawska-piatkowska@zut.edu.pl 
The average duration of intercourse in cows in the country was 432 days in 2015, 431 days a year later. One year later, 431 days. In the years 2015-2018 this period lasted for cows in the Kujawsko-Pomorskie Voivodship 430 days.

The voivodeship was characterized by an interquartile period of 430 days between 2015 and 2016. In 2015, the average milk yield of cows was 7.5-7.9 thousand. $\mathrm{Kg}$ at the first calving age of 804 days and the interval of 430 days. According to Krzyżewski et al. (2004) many negative phenomena are accompanied by the development of increasing milk yield. It is therefore very important for Polish breeders to consciously make decisions about increasing their production efficiency while maintaining animal welfare and high quality dairy products. More attention is paid to the reproductive traits and the factors influencing them. According to Brzozowski et al. (2001), the age at first calving is one of the most important factors affecting fertility, length of use and cows production. An important aspect is choosing the right moment to shed the cows.

The purpose of this study was to evaluate the effect of first calving age and interval length on milk production of cows in first and second lactations.

\section{MATERIAL AND METHODS}

The research was conducted in the Kujawsko-Pomorskie voivodship. The research material consisted of 103 cows of Polish Holstein-Friesian breed black and white (phf, cb). The work analyzes selected breeding parameters: age of first calving (WPW) and period of intergranulation (OMW). Data on milk yield and selected reproductive parameters were obtained based on the farm documentation of the farm using the results of the evaluation of the dairy cattle use value carried out by PFHBiPM. Evaluation of cows' usability (milk yield, fat and protein $(\mathrm{kg})$ and fat and protein content) included 305 days of lactation. Because of the age on first day of calving (WPW) four age classes were identified: I $-<24$, II $-25-27$, III - 28-30, IV $->30$ months. Considering the length of the intergalactic period (OMW), the following classes are listed: I $-<382$, II $-383-470$, III $->471$. The significance of the differences was calculated by one-way analysis of variance, using Duncan's multiple stretch test using the Statistica ${ }^{\circledR} 12$ PL program.

\section{RESULTS AND DISCUSSION}

Table 1 shows the results of milk yield of cows based on the first calving age in two consecutive lactations. By studying the effects of the first calving age, cows calving between the 25th and 27th month, the second best lactating cows, achieved $358 \mathrm{~kg}$ of fat. The highest content of fat $(4.50 \%)$ and protein yield $(289 \mathrm{~kg})$ in milk were found in cows calved after 31 months of life in the second lactation. The highest protein content $(3.42 \%)$ was observed in cows, Also in the second lactation.

The highest milk yield $(8001 \mathrm{~kg})$ in the first lactation was with cows whose first calving age was between 28 and 30 months. In second lactation, the highest milk yield was achieved by cows whose first calving age was between 25 and 27 months. Similarly, in studies of Czerniawska-Piątkowska et al. (2009), domestic cows were characterized by earlier age of 
first calving (WPW) than cows imported from Germany. WPW cows abroad, in the spring season was 820 days. In our own studies the age of first calving was longer and amounted to 837 days (Table 1). The highest yields of fat $(358 \mathrm{~kg})$ reached cows in the second lactation, whose first calving age was $25-27$. Month of life, while the highest protein yield $(289 \mathrm{~kg})$ reached cows calved over 31 months of age also in the second lactation. The lowest values were found in cows, who were born in the first and second lactations before the 24th.

Table 1. Mean smallest squares for lactating performance traits depending on the effect of first calving age

Tabela 1. Średnia najmniejszych kwadratów dla cech związanych z wydajnością laktacyjną, w zależności od wieku pierwszego wycielenia (WPW)

\begin{tabular}{|c|c|c|c|c|c|c|c|}
\hline 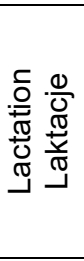 & $\begin{array}{l}\text { Age at first } \\
\text { calving } \\
\text { [months] } \\
\text { Wiek } \\
\text { pierwszego } \\
\text { wycielenia } \\
\text { [miesiące] }\end{array}$ & $\mathrm{n}$ & $\begin{array}{c}\text { Milk yield } \\
\text { Wydajność } \\
\text { mleka } \\
{[\mathrm{kg}]}\end{array}$ & $\begin{array}{c}\text { Fat yield } \\
\text { Wydajność } \\
\text { tłuszczu } \\
{[\mathrm{kg}]}\end{array}$ & $\begin{array}{c}\text { Fat content } \\
\text { Zawartość } \\
\text { tłuszczu } \\
{[\%]}\end{array}$ & $\begin{array}{c}\text { Protein yield } \\
\text { Wydajność } \\
\text { białka } \\
{[\mathrm{kg}]}\end{array}$ & $\begin{array}{c}\text { Protein } \\
\text { content } \\
\text { Zawartość } \\
\text { białka } \\
{[\%]}\end{array}$ \\
\hline \multirow{4}{*}{1} & $<24$ & 27 & $6776 \pm 1911.38$ & $322 \pm 125.73$ & $4.27 \pm 0.52$ & $228 \pm 64.04$ & $3.35 \pm 0.31$ \\
\hline & $25-27$ & 30 & $7610 \pm 1716.02$ & $306 \pm 70.20$ & $3.97 \pm 0.45$ & $249 \pm 57.42$ & $3.36 \pm 1.13$ \\
\hline & $28-30$ & 28 & $8001 \pm 1870.41$ & $316 \pm 75.69$ & $3.95 \pm 0.41$ & $257 \pm 62.64$ & $3.20 \pm 0.29$ \\
\hline & $>31$ & 18 & $6952 \pm 1340.05$ & $290 \pm 68.93$ & $4.05 \pm 0.48$ & $222 \pm 60.50$ & $3.24 \pm 0.29$ \\
\hline \multirow{4}{*}{2} & $<24$ & 23 & $7288 \pm 2059.57$ & $305 \pm 87.58$ & $4.18 \pm 0.39$ & $248 \pm 72.30$ & $3.42 \pm 0.19$ \\
\hline & $25-27$ & 27 & $7967 \pm 2318.18$ & $358 \pm 75.16$ & $4.06 \pm 0.43$ & $260 \pm 85.44$ & $3.29 \pm 0.23$ \\
\hline & $28-30$ & 16 & $6997 \pm 1864.48$ & $309 \pm 86.04$ & $4.29 \pm 0.38$ & $228 \pm 62.58$ & $3.26 \pm 0.10$ \\
\hline & $>31$ & 11 & $6689 \pm 1779.12$ & $302 \pm 89.80$ & $4.50 \pm 0.68$ & $289 \pm 203.24$ & $3.31 \pm 0.22$ \\
\hline
\end{tabular}

In Sitkowska et al. (2009) recorded the highest yields in cows that were first cured between 24 and 26 months of age. On the other hand, in Gulinski et al. (1996) the optimal age of the first calving was for the 27th month of life. In their own study, animals aged over 31 months had the highest milk fat content $(4.50 \%)$ in the second lactation. In contrast, the highest protein content in milk was recorded in cows that were ejaculated before 24 months of age, also in the second lactation. The lowest protein content (3.20\%) was characterized by cows, whose first calving age was 28-30. Months of life. In Bortackie et al. (2016) the highest protein content of the three analyzed lactations was found in cow's milk calcined for the first time under 23 months. By investigating the effect of intercourse length (OMW) on cow milk production (Table 2), it was observed that cows in the second lactation had the best milk yields. The highest milk yield $(8481 \mathrm{~kg})$ and fat yield $(355 \mathrm{~kg})$ reached cows with a mean interval greater than 471 days. Cows with an interval of less than 382 days were characterized by the highest fat content $(4.30 \%)$ and the highest protein yield $(424 \mathrm{~kg})$, while the highest protein content (3.42\%) was achieved by cows with an intergalactic period of 383-470 days. Bortacki et al. (2016) investigated the effect of interval length on milk yield of cows in individual lactations, found that the highest average milk yield was obtained for cows in second and third lactations, 11493.38 and $11401.33 \mathrm{~kg}$, respectively, with interval of $>401$ days, respectively.

The intercurrent period as one of the fertility indicators is the basis for cattle breeding and rearing since birth is a factor that triggers the production of milk. In some publications, it was 
found that the milk yield increased in the interval of growth (Gulinski et al. 1996; Hibner 1999; Czaplicka et al. 2003; Bogucki et al. 2007). In analyzing the values of selected cows fertility indexes with different lactating yields, The mean OMW length was 416 days and was slightly lower than the self-reported average OMW of 463 days. In the studies of Jankowska et al. (2012) interval was 366 days with 305 days of lactation. According to Juszczak et al. (2001), the most favourable boundary of the intergalactic period is 360 to 400 days.

Table 2. Mean least squares for lactating performance traits, depending on the length of the intermittent period

Tabela 2. Średnie najmniejszych kwadratów dla cech związanych z wydajnością laktacyjną, w zależności od długości okresu międzywycieleniowego (OMW)

\begin{tabular}{|c|c|c|c|c|c|c|c|}
\hline 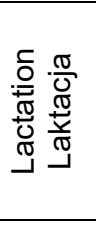 & $\begin{array}{c}\text { Calving } \\
\text { interval [days] } \\
\text { Okres } \\
\text { między- } \\
\text { wycieleniowy } \\
\text { [dni] } \\
\end{array}$ & $\mathrm{n}$ & $\begin{array}{c}\text { Milk yield } \\
\text { Wydajność mleka } \\
{[\mathrm{kg}]}\end{array}$ & $\begin{array}{c}\text { Fat yield, } \\
\text { Wydajność } \\
\text { tłuszczu } \\
{[\mathrm{kg}]}\end{array}$ & $\begin{array}{c}\text { Fat content, } \\
\text { Zawartość } \\
\text { tłuszczu } \\
{[\%]}\end{array}$ & $\begin{array}{l}\text { Protein yield } \\
\text { Wydajność } \\
\text { białka } \\
{[\mathrm{kg}]}\end{array}$ & $\begin{array}{c}\text { Protein } \\
\text { content } \\
\text { Zawartość } \\
\text { białka } \\
\text { [\%] }\end{array}$ \\
\hline \multirow{3}{*}{1} & $<382$ & 25 & $7488 \pm 2035.38$ & $297 \pm 85.22$ & $3.94 \pm 0.55$ & $234 \pm 72.64$ & $3.18 \pm 0.32$ \\
\hline & $383-470$ & 27 & $7079 \pm 1725.45$ & $305 \pm 70.95$ & $4.10 \pm 0.47$ & $243 \pm 60.23$ & $3.32 \pm 0.39$ \\
\hline & $>471$ & 24 & $6874 \pm 1084.28$ & $307 \pm 111.01$ & $4.19 \pm 0.49$ & $222 \pm 38.06$ & $3.42 \pm 1.24$ \\
\hline \multirow{3}{*}{2} & $<382$ & 23 & $6893^{a} \pm 2209.97$ & $318 \pm 90.16$ & $4.30 \pm 0.51$ & $242 \pm 68.86$ & $3.32 \pm 0.17$ \\
\hline & $383-470$ & 27 & $6962^{b} \pm 1961.78$ & $297 \pm 90.93$ & $4.18 \pm 0.32$ & $244 \pm 158.16$ & $3.42^{\mathrm{a}} \pm 0.24$ \\
\hline & $>471$ & 25 & $8481^{\mathrm{ab}} \pm 1641.06$ & $355 \pm 63.40$ & $4.09 \pm 0.47$ & $278 \pm 56.56$ & $3.27^{a} \pm 0.19$ \\
\hline
\end{tabular}

$a, b$ - the mean in columns in lower case letters means difference in level $P \leq 0.05$ - średnie w kolumnach oznaczone małymi literami oznaczają różnice na poziomie $\mathrm{P} \leq 0,05$.

It was found that the highest milk yield $(8481 \mathrm{~kg})$ was obtained by cows whose intercostal period exceeded 471 days in the second lactation. In contrast, the lowest yields were observed in cows during first lactation, of which OMW was greater than 471 days $(6874 \mathrm{~kg})$. During the first lactation, prolongation of the intercostal period did not favour improvement of milk yield of cows. At the next lactation, the milk yield increased significantly with the prolonged interval. Studies have shown that fat and protein yield during the first and second lactations are similar. The highest yields of fat and protein were recorded during the second cure, in cows, the intercourse was 471 days for fat $(355 \mathrm{~kg})$ and less than 382 days for protein $(424 \mathrm{~kg})$. Cichocki et al. (1999) found that milk and fat yields increased with increasing the interval. In the own studies, a slight increase in milk yield was also observed as the interval was increased.

This dependence was noted for OMW during the whole first lactation period. In the second lactation, there was a decrease in productivity up to 470 days, while over 471 days had an increase in milk yield. When analysing the fat and protein content of milk in the tested herd, similar values of the discussed ingredients in both first and second lactations were reported. Fat content was significantly different from protein content. The highest content of fat $(4.30 \%)$ in milk was found in cows with an interval of less than 382 days. In turn, the lowest milk fat content $(3.94 \%)$ was obtained in first lactating cows, of which OMW was less than 382 days. 
The protein content was similar. Cows, with an interval greater than 471 days, achieved the highest protein content $(3.42 \%)$, first lactation and second lactating cows with OMW of $383-470$ days. The lowest protein content $(3.18 \%)$ was achieved by cows whose interval was less than 382 days in the first treatment.

\section{CONCLUSION}

To sum up the results of this study, significant differences $(P \leq 0.05)$ between the studied animal groups should be noted. The highest milk yield $(8481 \mathrm{~kg})$ and fat yield $(355 \mathrm{~kg})$ reached cows in the second lactation, with an interval greater than 471 days. There were significant differences $(P \leq 0.05)$ in the tested herd as a percentage of milk protein depending on the length of the interval. The highest protein content in milk was recorded in second lactation (3.42\%) in the group of 382-470 OMW cows. Studies have shown that the cowshed aged between 28-30. Month of life results in higher milk yield in first lactation. The highest content of protein $(3.42 \%)$ was found in cows that had fallen before 24 months of age. These results indicate that the most favourable intercourse period is 471 days, while the first calving age below 24 months results in the lowest lactation yield.

\section{REFERENCES}

Bogucki M., Sawa A., Neja W. 2007. Zróżnicowanie wskaźników płodności krów mlecznych w związku ze wzrastająca wydajnością laktacyjną [Diversity of fertility rates for dairy cows in relation to increasing lactating yields]. Acta Sci. Pol., Zootech. 6(3), 3-10. [in Polish]

Bortacki P.,Kujawiak R., Czerniawska-Piątkowska E., Wójcik J., Grzesiak W. 2016. Influence of the age on the day of first calving and the length of calving intervals on the milk yield of cows. Folia Pomer. Univ. Technol. Stetin., Agric., Aliment., Pisc., Zootech. 325(37) 1, 5-12.

Brzozowski P., Zdziarski K., Grodzki H. 2001. Długość użytkowania, wydajność życiowa i płodność krów rasy czarno-białej, holsztyńsko-fryzyjskiej oraz mieszańców tych ras niezależnie od wieku pierwszego ocielenia [The length of life, fertility and fertility of black-and-white, Holstein-Friesian cows and hybrids of these breeds regardless of the age of the first calving]. Pr. Mater. Zootech. 59, 71-76. [in Polish]

Cichocki M., Kijak Z., Wielgosz-Groth Z., Wroński M. 1999. Długość okresu międzywycieleniowego i jego wplyw na mleczność krów użytkowanych w regionie północno-wschodniej Polski [Length of the intercurrent interval and its effect on the milking of cows used in the north-eastern region of Poland]. Zesz. Nauk. Prz. Hod. 44, 91-98. [in Polish]

Czaplicka M., Puchajda Z., Szalunas T. 2003. Porównanie długości laktacji, okresu międzywycieleniowego oraz wydajności mleka w czterech laktacjach krów importowanych z Francji $i$ krajowych cb [Comparison of lactation length, intercurrent interval, and milk yield in four lactations of cats imported from France and domestic black and white]. Zesz. Nauk. Prz. Hod. 68(1), 107-113. [in Polish]

Czerniawska-Piątkowska E., Szewczuk M., Sowa A., Żychlińska-Buczek J. 2009. Porównanie poziomu cech produkcyjnych krów rasy HF importowanych z Niemiec z rówieśnicami krajowymi [Comparing the level of production characteristics of HF cows imported from Germany with the national same age]. Acta Sci. Pol., Zootech. 8(3), 3-10. [in Polish] 
Guliński P., Litwińczuk Z., Młynek K. 1996. Wpływ wybranych czynników genetycznych i środowiskowych na związek pomiędzy długością okresu międzywycieleniowego a użytkowością mleczna krów [The influence of selected genetic and environmental factors on the relationship between the length of the inter-period and milk yield of cows]. Rocz. Nauk. Zootech. 23(4), 9-17. [in Polish]

Hibner A., Zachwieja A., Juszczak J., Ziemiński R. 1999. Efektywność produkcji mleka w stadach wysokowydajnych w aspekcie zróżnicowanej długości cyklu reprodukcyjnego krów [Effectiveness of milk production in high-performance herds in terms of varied length of reproductive cycle of cows]. Med. Weter. 55, 753-756. [in Polish]

Jankowska M., Neja W., Kężel-Czopek S. 2012. Effect of extender lactations on milk and reproductive performance of cows. Acta Sci. Pol., Zootech. 11(2), 15-22.

Juszczak J., Machal L., Hibner A. 2001. Wiek cielenia się jałowic, jako czynnik efektywności użytkowania mlecznego krów [The age of calving heifers, as a factor in the milk cow's milk efficiency]. Prz. Hod. 5, 18-20. [in Polish]

Krzyżewski J., Strzałkowska N., Reklewski Z., Dymnicki E., Ryniewicz Z. 2004. Wpływ długości okresów międzyciążowych u krów rasy Hf na wydajność, skład chemiczny mleka oraz wybrane wskaźniki rozrodu [Effect of length of intermittent periods in Hf cows on performance, chemical composition of milk and selected reproduction ratios]. Med. Weter. 60(1), 76-7. [in Polish]

PFHBiPM. 2016. Wyniki oceny wartości użytkowej krów mlecznych za rok 2015. Warszawa, PFHBiPM. [in Polish]

PFHBiPM. 2017. Wyniki oceny wartości użytkowej krów mlecznych za rok 2016. Warszawa, PFHBiPM. [in Polish]

Sitkowska B., Mroczkowski S., Topolewska A. 2009. Wpływ wieku w dniu pierwszego wycielenia oraz długości okresu międzycieleniowego na produkcyjność mleczną krów [Influence of age at day of first calving and interval length on milk production of cows]. Zesz. Nauk., Zootech. (252)37, 99-107. [in Polish]

Wyniki oceny wartości użytkowej krów mlecznych (część analityczna). 2015. Warszawa, PFHBiPM. [in Polish]

Wyniki oceny wartości użytkowej krów mlecznych (część analityczna). 2016. Warszawa, PFHBiPM. [in Polish]

\begin{abstract}
The research was conducted in the Kujawsko-Pomorskie voivodship. The study material consisted of 103 cows of the Polish Holstein-Friesian breed black and white (phf, cb), considering selected breeding parameters: age of first calving (WPW) and intermittent period (OMW). Data on milk yield and selected reproductive parameters were obtained from the farm documentation of the farm using the results of the evaluation of the dairy cattle use value carried out by PFHBiPM. Milk yield of cows was assessed based on milk yield, fat and protein [kg] and content [\%] of these components in milk. When analysing the intercurrent period of cows, significant differences $(P \leq 0.05)$ were observed between the examined animal groups. The highest milk yield $(8481 \mathrm{~kg})$ and fat yield $(355 \mathrm{~kg})$ reached cows in the second lactation, with an interval greater than 471 days.
\end{abstract}

